\title{
Gender Differences in the Undergraduates' Attitudes towards EFL
}

\author{
Daoshan Ma \\ School of Foreign Languages, Tianjin Polytechnic University, Tianjin, China
}

\begin{abstract}
In this thesis, the seniors from six main universities in Tianjin are investigated on their attitudes towards EFL. Data are collected through questionnaires and analyzed by gender which shows that girls hold a more positive attitude to EFL than boys.
\end{abstract}

Index Terms - EFL, attitude, gender difference

\section{INTRODUCTION}

A learner's social psychology consists of his attitude, motivation, self-identify, and so on, which are important components of the research on language learning. Attitude is how people consider themselves and the state of their social existence, which is a stable internal psychological statement with a certain structure. As a kind of important social psychological phenomenon, attitude has some features, such as, sociability, subjective experiential infectiousness and dynamic function.

S. Rosenberg and C. I. Hovland (2003) consider that attitude consists of three elements, which are believed to be cognition, emotion, and behavior tendency. This point of view seems to have been already approbated by most social psychologists. As a matter of fact, the cognitive element of the attitude is a statement with judgments, which includes the understanding and comprehension of the attitudinal objective. Emotion means emotional experience of the attitude towards the attitudinal objective, such as favor, averseness, sympathy and sneer. Behavior tendency is a kind of internal response, which is a prepared state kept by a person before acting (Ma, 2014). In the light of attitude measuring, it seems obvious that emotion index will be more effective and convenient for using than other indexes if we make an investigation on the attitude of the students. No one denies that English study is influenced by the interaction of cognition and emotion. (Chang, Kang \& Wang, 2005, p.730)

Because attitude is a kind of inward psychogenic state, it is not visible. So researchers can only find it by observing people's external actions. Different styles of scales have been widely used in attitude measurement, such as equal interval scales, summated rating scales and semantic differential scales. All of these scales are auto critical methods. Attitude is not congenital but must be acquired from process of socialization. Once shaped, it will be relatively stable. The society he lives in, the family he is living with, the companion he is working in and the organization he is affiliated with all play momentous roles in forming one's attitude.

Many researches on English learners' motivation have been made and some achievements have been gained. Some of them mainly consider that students take the College English Test with clear tendency of utilitarian purposes. (Ma, 2005: 259; Ma, 2014) The reason why most Chinese university students have to work hard at English learning is not because they have a very strong motive of learning it, but because they have to adapt themselves to the social demands. (Huang \& Wen, 2005: 34; Ma, 2014) However, the function of CET is limited in evaluating the present quality of English teaching in Chinese universities. (Tang, 2005: 59; Ma, 2014) The present test is claimed to be lacking of reliability and validity, because it is designed and performed in one aspect as to be devoid of having ever tested the students of their social communicative ability. (Wang, 2005: 52) In recent years, the employers in China are gradually turning to be dissatisfied with the university student for their poor comprehensive ability of English. At the same time, the subjects are just guided by CET without paying due attention to developing their communicative competence. (Tang, 2005: 65) A program directed by Gao Yihong (2004: foreword), is focusing itself on a multi-angular and systematical study on the motivation and the self-identification of Chinese university English learners, which has made considerable achievement because of the professional and rigorous scientific approach.

It seems that among those researches mentioned above, the gender difference of the college students' attitude to CET has not been well studied (Ma, 2014). Due to some limitations, the author has not found much data in this field(Ma, 2014).

\section{RESEARCH METHOD}

Questionnaires are often in common use for multifarious investigations because it's handy and convenient to be controlled (Ma, 2014). For those advantages the author again chooses this method to accomplish the investigation (Ma, 2014). 


\section{A. Research Objective}

This research is merely conducted among a small crowd. As a special colony, senior students have to face job-hunting after graduation (Ma, 2014). But previous researches are generally aimed at an investigation on the freshmen and sophomores or third year students (Ma, 2014). Hence, the objective of this thesis is aimed at seniors from non-English majors who have passed the written-examination of CET. Those who have not passed the test are not to be chosen for the reason that their attitudes are not to be affected by the pressure (Ma, 2014).

\section{B. Process of Research}

The questionnaire is a descriptive one, compiled and made up of three parts with 31 questions. The first part is composed of some basic information about the student and his or her English level (Ma, 2014). The second part, which adopts the method of Likert scale, is made of single choice questions with 20 declarative sentences which should be chosen from five options to best express the student's attitude. The last part is multinomial choice with 6 questions (Ma, 2014).

46 questionnaires are handed out by some senior students in six main universities in Tianjin, which are Nankai University, Tianjin Polytechnic University, Tianjin University, Tianjin Medical University, Tianjin Normal University, and Tianjin Commercial University, and 41 questionnaires are valid with a rate of $89 \%(\mathrm{Ma}, 2014)$. Among the subjects, there are 23 male students from different universities, and 18 female students, who are from 14 different majors of liberal arts, science, medicine, and art etc (Ma, 2014).

There are many influential factors which are involved in the formation of one's attitude, so some of those factors need to be controlled in certain context. And with the imbalanced development of Chinese economy and education, there are some differences in people's command of English language in different regions (Ma, 2014). To make the result more typical and to limit the influence of regional difference, the author chooses students who come from different regions of the north and the south in China (Ma, 2014). Besides, gender ratio, major of the students and representatives of the universities are all considered. Since the questionnaire is to describe the seniors' attitudes towards College English Test but not to be used as research tools, the data collected was not processed for complicated statistical analysis (Ma, 2014).

\section{DATAANALYSIS}

To analyze the gender difference of the attitudes between the boys and the girls who are tested, in this part, data is counted separately. In the attitude investigation items, girls get higher marks than boys. Two-thirds of them are marked over 40, which is about ten percentages higher than the boys'. All of the three students who are marked lower than 30 are boys. Therefore, we may easily arrive at a conclusion that girls hold a more positive attitude to College English Test compared to boys.

Boys and girls appear to have differences more or less in most of the items we have investigated. The differences are especially embodied in items 1, 2, 3, 4, 6, 7, 9, 11, 13, 14, 16, 17, 18 and 20. Specific analysis is given as follows:

In item 1, half of the girls approve that the high score that the university students have got in CET could prove that they are good at English learning. Correspondingly, fewer boys do the same (35\%) and nearly one-third of them (30\%) have no idea about this. That means boys do not think there would be some relationship between their grades and their ability of learning. It seems that boys hold a more rational attitude towards CET than girls.

In item 2, 61\% of the girls agreed that the ability to use English as a foreign language is actually much more important than CET school reports, while, as high as $83 \%$ of the boys did the same. We can see that boys put more emphasis on what they have mastered. More boys think that in the future their employers would consider it more important for them to speak and write in English than to get high grades in the examinations at the universities.

In item 3,78\% of the boys and 50\% of the girls complain that the current College English Test is not practical. Once more we have found that students are not satisfied with College English Test. More boys than girls hold a negative attitude towards CET because they think that the test is lack of practical contents.

In item 4, more boys hold a viewpoint that the current College English Test could evaluate the students' present work on English and it could bring their present state of English learning to light, and at the same time, there are also more boys than girls who disagree with it. This might show that the boys' attitude is more definite and more radical than that of the girls.

In item 6, more girls give positive opinions to the current reformation in the content and the modality of College English Test, only $30 \%$ of the boys present similar view. This shows that girls are more optimistic than boys in the belief that the test could be revised to focus itself on testing the communicative ability of the students and made itself more acceptable to the public.

Nevertheless, in item 7, as high as $39 \%$ of the boys disagree with the school reports, which has been an important part of the reform on CET, but they agree that this reduces the value of CET. As many as half of the girls have no clear ideas about it because they do not feel any difference after the reform. This might show that girls are not very sensitive to whether CET school reports or CET certificates are issued, and more boys than girls are dissatisfied with CET school reports and consider the new method of issuing CET grades in the form of school reports a disaster.

In item 9 , there are $22 \%$ of the girls who consider themselves of going abroad or hunting jobs in foreign-invested 
companies after obtaining CET school reports, however, only $4 \%$ of the boys have the same idea. Dramatically, $61 \%$ of the girls oppose that they would go abroad for further studies or work in overseas-funded enterprises after their graduation, a percentage even higher than that of the boys. Thus, girls express themselves more strongly than boys about this problem. More girls than boys wouldn't relate their future employments with their CET performances.

In item 11, there are no boys who oppose the statement that it is of more importance for them to master professional knowledge rather than English while 12\% of girls do so. The author conjectures that the phenomenon is caused by the pressure of job-hunting for girls. This result exactly echoes with the statistics of item 16, that CET school report is more important for girls. This seems that girls feel more pressured in their hunting for decent jobs than boys, although they, as mentioned in the above paragraph, don't think that their future jobs should be related with English.

In item 13, though there are $45 \%$ of the girls who agree that College English is useless, almost an equal quantity of the students is with the opposite opinions. The boys' choice is much evident that $69 \%$ of them are approvers and about one-fifths $(21 \%)$ are disapprovers. More of the male subjects than the female subjects think that the current College English course is not in conformity with what they need.

In item $14,56 \%$ of the girls feel they cannot learn enough knowledge from professional English courses, whereas fewer than one-fifths (17\%) of them are against it. Most of the boys do not agree, and only 30\% of them uphold the statement. This reveals the fact that more girls are dissatisfied with the present professional English course while more boys think that they can actually learn something useful from this course.

As mentioned above, in item 16, 67\% of the girls think CET school report is much more important for them. While, only $35 \%$ of the boys hold the same opinion. This discloses such information that the girls rate CET school report much higher than the boys and it might be true that gender discrimination in job-hunting still exists unfortunately in a wide range of the walks of life.

In item 17, the girls holding opposed attitudes are in excess of the female approvers, whose proportion is $44 \%$ to $39 \%$. $17 \%$ of the boys hold the negative opinion, much less than that of girls. More female subjects are requiring their teachers of improving their teaching methods and their teaching skills.

In item 18 , as high as $22 \%$ of the girls argue against the idea that professional English is necessary. Only $8 \%$ of the boys disagree with it. The reason is not found in this research and needed to make more investigations.

In item 20,61\% of the boys meet with the difficulty of speaking English freely. However, the condition is not so terrible for girls as only $28 \%$ of them have to face this problem. This shows that more male subjects than female subjects feel it is urgent for them to improve their ability to speak English and it might be much easier for girls to learn a foreign language than for boys.

\section{LIMITATIONS}

Because of limited time and lack of references, the investigated items in the questionnaire are a little scattered and need to be perfected (Ma, 2014). Another problem is that questionnaires are all handed out by some seniors, so students investigated might not be serious enough in their choices. (Ma, 2014) There might also be some misunderstandings on the same item for different students, which will interfere with them in making their choices (Ma, 2014).

If the subjects invested are from different universities, and from different cities, this investigation would be more convincing (Ma, 2014). If there are some voices from the employers, it would be more persuading (Ma, 2014).

Though the investigated subjects are various and comparatively typical, the quantity of investigation is not big enough (Ma, 2014). It is still worthy of doing further researches in the future and most of the limitations can be settled (Ma, 2014).

\section{APPENDIX. QUESTIONNAIRE}

Dear friend,

Hi. This questionnaire is designed to make a survey on your attitude towards CET-4 and CET-6. Please answer the following questions carefully and express what you really feel about the test according to the following requirements. This will take you some of your precious time and we are grateful to your help.

Part One: Background information.

Please write your corresponding information on the line or put a tick on the line.

I am___ male or ___emale.

I am/have been graduated from ___ University.

My major is

I am from $\longrightarrow$ (Province or city).

I have passed ___ CET-4 or ___ CET-6 or ___ both.

Part Two: Please choose one item that best expresses your opinion and click the corresponding letter marked with A, $\mathrm{B}, \mathrm{C}, \mathrm{D}$ or E.

1. I think that excellent achievements of the CET-4 and CET-6 may prove that my ability of learning is remarkable, and poor performance may show that my ability of learning is also poor.
A. I agree with it very much.
B. I agree with it.
C. I don't know. 

D. I don't agree.
E. I don't agree with it at all.

2. I think the practical ability of using English language is more important than the results of the CET-4 and CET-6.
A. I agree with it very much.
B. I agree with it.
C. I don't know.
D. I don't agree.
E. I don't agree with it at all.

3. I think that what CET-4 and CET-6 test us is not very practical.
A. I agree with it very much.
B. I agree with it.
C. I don't know.
D. I don't agree.
E. I don't agree with it at all.

4. I think that CET-4 and CET-6 can test out my level of learning in College English course.
A. I agree with it very much.
B. I agree with it.
C. I don't know.
D. I don't agree.
E. I don't agree with it at all.

5. I think that the results of CET-4 and CET-6 may show the actual performance of my English language learning.
A. I agree with it very much.
B. I agree with it.
C. I don't know.
D. I don't agree.
E. I don't agree with it at all.

6. I think that the changes that have taken place in the reform of CET-4 and CET-6 have made great progress in testing a foreign language.
A. I agree with it very much.
B. I agree with it.
C. I don’t know.
D. I don't agree.
E. I don't agree with it at all.

7. I think that the school report of CET-4 and CET- 6 by issuing a report card instead of the original certificates does nothing but reduces the importance of the test itself.
A. I agree with it very much.
B. I agree with it.
C. I don't know.
D. I don't agree.
E. I don't agree with it at all.

8. I think that the school report of CET-4 and CET-6 is a first step forward to the success of hunting a job.
A. I agree with it very much.
B. I agree with it.
C. I don't know.
D. I don't agree.
E. I don't agree with it at all.

9. After I have passed the tests, I am considering of the possibility of going abroad for further studies or entering an overseas-funded enterprise to work.
A. I agree with it very much.
B. I agree with it.
C. I don't know.
D. I don't agree.
E. I don't agree with it at all.

10. I think that the school report of CET-4 and CET-6 is much more reasonable than the certificates of qualification.
A. I agree with it very much.
B. I agree with it.
C. I don't know.
D. I don't agree
E. I don't agree with it at all.

11. I think that professional skills and knowledge are more important than the grades of CET-4 and CET-6.
A. I agree with it very much.
B. I agree with it.
C. I don't know.
D. I don't agree.
E. I don't agree with it at all.

12. I think that the textbooks of College English are far more different in contents from what CET- 4 and CET- 6 test us.
A. I agree with it very much.
B. I agree with it.
C. I don't know.
D. I don't agree.
E. I don't agree with it at all.

13. I think that the courses of College English have been proven to be of limited use.
A. I agree with it very much.
B. I agree with it.
C. I don't know.
D. I don't agree.
E. I don't agree with it at all.

14. I think that I have learned nearly nothing of use in the course of professional English for non-English majors.
A. I agree with it very much.
B. I agree with it.
C. I don't know.
D. I don't agree.
E. I don't agree with it at all.

15. I think that the courses should be designed to include more for the students' practical needs in the future.
A. I agree with it very much.
B. I agree with it.
C. I don't know.
D. I don't agree.
E. I don't agree with it at all.

16. I think that the original CET-4 and CET-6 certificates are of more importance to me than the present school reports.
A. I agree with it very much.
B. I agree with it.
C. I don't know.
D. I don't agree.
E. I don't agree with it at all.

17. I think that the results of the CET-4 and CET-6 are closely related with the teacher's performance.
A. I agree with it very much.
B. I agree with it.
C. I don't know.
D. I don't agree.
E. I don't agree with it at all.

18. I think that professional English for non-English majors is quite necessary.
A. I agree with it very much.
B. I agree with it.
C. I don't know.
D. I don't agree.
E. I don't agree with it at all.

19. I think that it is more difficult to improve my writing than my speaking in English.
A. I agree with it very much.
B. I agree with it.
C. I don't know.
D. I don't agree.
E. I don't agree with it at all. 
20. I think it is very difficult for me to improve my speaking in English.
A. I agree with it very much.
B. I agree with it.
C. I don't know.
D. I don't agree.
E. I don't agree with it at all.

Section Three

Please choose on or more items that most suits to your opinion, you may tick the corresponding letter marked with A, B, C, D.

1. What do you plan to do after your graduation?
A. For further studies
B. Joining the work force.
C. Going abroad.
D. Other choices.

2. What courses have you attended before?
A. The training courses for CET-4 and CET-6.
B. The training courses for postgraduate entrance examination.
C. TOEFL
D. IELTS
E. GRE
F. Oral English
G. No courses.

3. What ability do you want to approve yourself most?
A. Oral English
B. Listening comprehension
C. Reading comprehension.
D. Writing. E. Translation

4. What kind of job do you like to hunt?
A. Stat-owned enterprise
B. overseas-funded enterprise
C. Joint venture
D. a private enterprise
E. Government
F. Self employed

5. Which area would you like to work in?
A. The Pearl River area
B. The Yangtse Rive area
C. The Bohai Bay area

D. The Northeast Part of China.

E. The central plain area

F. The Southwestern Part of China.

G. The Western part of China.

H. The Northwestern part of China.

6. Which kind of place do you like to work in China?
A. big cities
b. medium-sized cities
C. small cities
D. towns E. villages

Thank you vey much for having filled in this form of questionnaire. Best wishes to you for a successful career!

\section{ACKNOWLEDGEMENT}

I'd like to take this opportunity to thank my former student, Wang Xiao, who has helped me in the whole course of the investigation. She has helped me in the collecting and analysis of the data. Without her help, this thesis would not have been possible.

\section{REFERENCES}

[1] Chang, Xin, Kang Tinghu \& Wang Pei. (2005). The influence of cognitive and emotional factors on college students in the process of English learning. The Science of Psychology 3. 2-15.

[2] Gao, Yihong. (2003). Social psychology of the Chinese college students in their English Studies. Beijing: Foreign Language Teaching and Education Press.

[3] Huang, Hongan \& Wen Weiping. (2005). A case study of the motive factors in the English studies for non-English majors. Foreign Language Teaching Abroad 3. 17-23.

[4] Liu, Runqing \& Dai Manchun. (2003). A research on the developing policy and reform on foreign language teaching in Chinese universities. Beijing: Foreign Language Teaching and Education Press.

[5] Ma, Daoshan. (2005). Should CET be cancelled? Yu Xiaodan (ed.) On foreign language research and teaching. Changchun: Jilin University Press.254-259.

[6] Ma Daoshan. (2014). A case study of the relationship between seniors' EFL attitudes and their employment intentions. Theory and Practice in Language Studies, Vol. 4, No. 7. 1434-1438.

[7] Ren, Yonggang. (2005). Medical English education after the reform on CET. Yu Xiaodan (ed.) On foreign language research and teaching. Changchun: Jilin University Press.260-265.

[8] Tang, Wenli. (2005). Analyses and investigation on the effect of motive factors on speaking. Foreign Language Teaching 2. 23-31.

[9] Tang, Xiongying. (2005). CET and College English course evaluation. Foreign Language Teaching 2. $42-47$.

[10] Wang, Zhengyuan. (2005). Counter-effect of English tests. Foreign Language Teaching 1. 11-16.

[11] China Higher Education Social Psychology Compiler Team. (2003). Social psychology. Tianjin: Nankai University Press.

Daoshan Ma, male, is a professor of the College of Foreign Languages, Tianjin Polytechnic University. His research interest includes syntax and comparative linguistics between English and Chinese. His major publications are: "Reflections on the Types of Natural Languages from the Perspective of Wh-movement" and "The Syntactic Evidence on the Chinese Interrogative Particle Ne". 